\title{
Spirituality in Place: Capturing the Essence of North Queensland through Painting
}

\author{
Barbara Cheshire \\ Ryan Daniel \\ College of Arts, Society \& Education, James Cook University
}

\begin{abstract}
For centuries, artists have been inspired by place. This perception and awareness of place can also involve a spiritual connection. Artists from both Aboriginal culture and white settlement in Australia have painted works which reveal a deep spiritual connection to place. One of the geographical areas that has inspired several artists is North Queensland, which offers a rich tapestry of dry and wet tropical environments. This article considers an historical overview and deconstructs the work of four contemporary painters (Firth-Smith, Silver, Watson, and Cheshire) who have been inspired by the place that is North Queensland, in order to consider the ways in which their work reveals a spiritual connection to place.
\end{abstract}

\section{Introduction: perception of place through a sense of the spiritual}

$\mathbf{I}^{\mathrm{t}}$ can be argued that at an intrinsic level of understanding, our perceptions include an awareness of place; in fact it is well documented that place has provided inspiration for artists for centuries (Drake, 2003). Gunton (1997) argues that all cultures, ancient and modern alike, seek a way of accounting for the universe that gives their lives coherence and meaning. Depending on a person's perceptive awareness, place can include a spiritual essence, a consciousness of the way the beauty of creation mirrors God. Hamma (1999) contends that places of all varieties have often evoked a sense of the sublime and can reveal the metaphysical in the physical. Thus, ordinary places can shape and form a spiritual consciousness and disclose a greater reality through a person's perception of them. From an artistic perspective, representations or paintings of these places combine both subjective and objective perception, yet may take it a step further into a holistic spiritual perspective.

A holistic spirituality is a perspective that is concerned with a developmental, experiential, integrative, and transformational attitude to life. Au (1989) describes holistic perspective as asserting the importance of a confluent approach that brings together the head and the heart, the cognitive and the affective in learning and living. Many religious traditions see spirituality as intimately connected with place (Hamma, 1999; Keating, 1996; Leder, 2004; McFague, 1993). Although they use their own conceptual language to articulate the sacred nature of the world, there is a harmony of feeling that transcends religious differences. For example, Leder (2004) sees a commonality in this instance of different religious beliefs: Christian - the spiritual significance in common things and actions; Hinduism - all that is seen are forms of God; Judaism - all organic and inorganic nature full of holy sparks; Goddess worship - Mother God is within all; Taoism - the world is sacred. Although this is only a 
small number of the world's religions, the common theme embedded in the examples is that the world is very much a place of God. ${ }^{1}$

Christianity has as its centre Jesus Christ of Nazareth, who is considered both God and human, divine and physical, creator and created. McFague (1993) argues Christianity to mean that "everything that is, is the sacrament of God (the universe as God's body)" (p. 162). In the Christian institutional church this philosophy is expressed through the Nicene Creed and in all aspects of the liturgy. Everything is interlinked, for instance, from the text through intonation, to priestly gestures, incense, candles, and artwork. Siedell (2008) argues that "what is interlinked is the experience of God's presence in and through all its components, which encompasses all of creation" (p. 142). However, the church from an organic perspective is where the vision of the liberating, healing, inclusive love of the embodied God occurs (McFague, 1993). This may occur in a church building, but it does also occur elsewhere. In the same way that this perspective includes the diversity and richness of all creation, including humanity, it indicates that each encounter, contemplation, and meditation in and on an environment is an encounter with the divine. Although contemplation and communion in and on place are disciplines that a religious artist can apply to learn and discover as they make their artwork, artists and viewers alike without any spiritual belief - can potentially use the same discipline to make and view artwork respectively.

\section{Spiritual art in Australia}

Since white settlement, many Australian artists have drawn on Judaic or Christian traditions and the root symbols of religion that located them in the context of great antiquity. The stylistic trends of Australian religious art have involved many approaches. Some artists, for example Davida Allen (b.1951), were committed Christians and painted out of a personal faith; Asher Bilu (b.1936) saw the truths of religion in abstract expression. Others, including Arthur Boyd (1920-1999), viewed the purpose of religious art as an inspiration, a biblical narrative or teaching tool, while some, for example David Giles (b.1967), felt the experience and expression of painting as a mystical dimension. Moon (2004) argues that the many different approaches to visual expression of religious painting in Australia give evidence that religious thinking, and the power of its symbols and accounts of human-divine interaction, still inform, inspire, and confront many artists. Indeed these are consistent with those "who seek a life close to God to involve themselves in creative work" (p. 52).

One can argue that the theme of spirituality in Australia is as ancient as art itself. The culture of Australian Aborigines is permeated by a profoundly spiritual essence; the power of the sacred which is sustained by an appropriate ideological underpinning (Crumlin, 1988; Drury \& Voigt, 1996; Nganjmirra, 1997; Were, 1997). For these peoples there is no separation between life and spirituality; everything "is a unity, a rhythm of the sacred, filled with meaning" (Crumlin, 1988, p. 11), in which art is a means of communicating certain hidden mysteries to the initiated. Through initiation

\footnotetext{
${ }^{1}$ It is acknowledged that there are various other forms of spirituality and religion, however the examples provided are intended to provide an insight into the link between the sacred, the worldly and place.
} 
during adolescence, the attainment of religious knowledge begins and remains a lifelong quest. Inner layers of meaning are not revealed to the uninitiated, therefore the context of their art contains many layers and is inseparable from Aboriginal life and cultural law. A conscious effort is required to penetrate beneath the surface of material things. The sacred may be displayed, but is invisible to a materialist interpretation. Nevertheless, the mythic narrative, the symbolisms of daily life and belief, the songs, dances, and religious ceremonies, are all enmeshed in the imagery of Aboriginal art.

Crumlin (1988) argues that Australia has also absorbed spirituality not only from Judaic Christian thought, but from a substantial migrant population, so it is not surprising that a diverse range of cultural traditions contribute to the shaping of Australian contemporary art. Although spirituality has fallen in and out of fashion in the Western world "as boundaries shift and dissolve within a global context" (Cree \& Drury, 2000, p. 9), it has been recognised as a significant element in artistic expression since the 1990s, and is thematic of many contemporary Australian painters who have explored spiritual and esoteric sources of inspiration (Cree \& Drury, 2000; Drury \& Voigt, 1996; Nicholls \& North, 2001). Artists William Ferguson (b.1932), Mirlkitjungu Millie Skeen (b.1935), Kathleen Petyarre (b.1940), Kate Briscoe (b.1944), and Marion Borgelt (b.1954) are examples of Australian painters who express an understanding of the mystical and spiritual through the experiential dimension of art. They draw personal attention to different pictorial devices used for signifying the spiritual. Each of these five artists have used common denominators to portray the spiritual in their paintings: a time zone, colour to represent emotional states and the energy of colour itself, universal symbolism to portray the concept, and "a strong element of attention to formalism in the compositions as an ongoing language of assessment" (Cree \& Drury, 2000, p. 52).

\section{An artistic attraction to North Queensland as place}

North Queensland, a large tropical region in the north-east of the country, has long attracted visiting artists from Australia and around the world. From the time that art was produced by the earliest European artists and naturalists in 1770 to the contemporary art of the twenty-first century, the range of genres and subject matter produced in North Queensland has been diverse. Nevertheless, the common thread in these works is the response to the tropical environment and the landscape. Searle (1991) argues that the contrasting environments and terrain within this geographical area have "overwhelmingly been the major concern of artists working in the region" (p. 9). An example of this approach can be seen in the painting by Graham Gore (Figure 1), where the human elements (boat and sailor) are dwarfed by the rich tropical environment. 


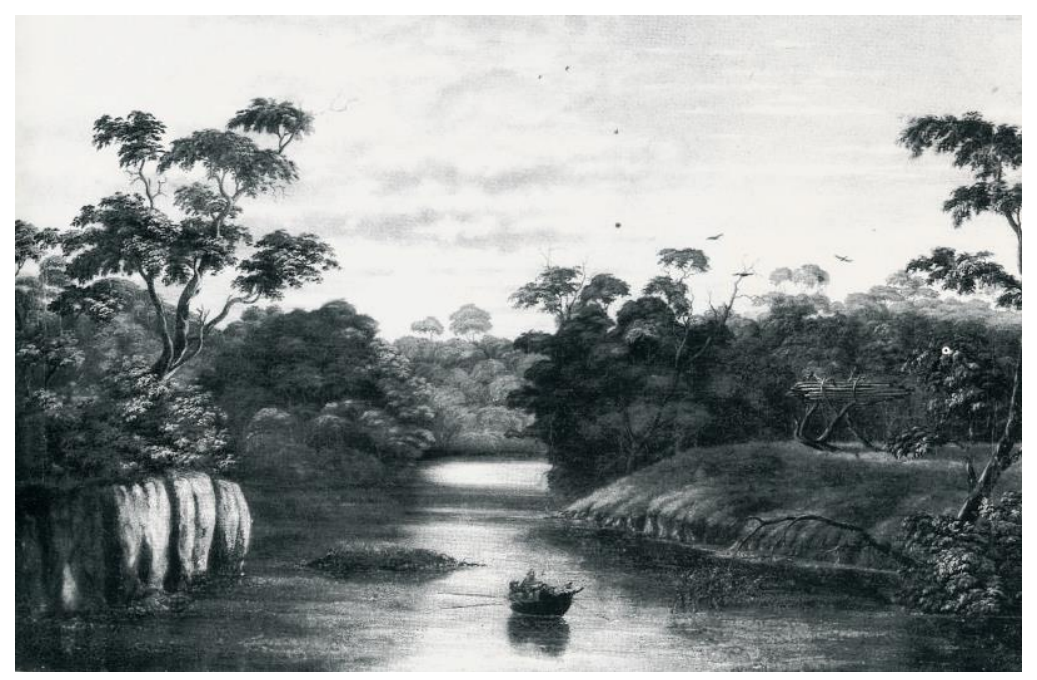

Figure 1: Graham Gore (1841), Burial reach, Flinders River, Queensland, oil on canvas, $61.2 \mathrm{~cm}$ x $91.9 \mathrm{~cm}$, National Library of Australia.

For many artists, the experience of life in North Queensland was a stimulant and key element in their work. Since the exploration and early settlement of this region, the role of subject matter and the concepts of art have been constantly changing. For example, Wilson (1998) argues that "in 1943-44 [Frank] Hinder was based in Townsville as an official camouflage artist ... [and] by a process of reduction and contrast, he has transformed a routine wartime experience into a surreal event of almost operatic proportions" (p. 52). New perceptions of the landscape and the coastline were introduced after aerial views were taken during the war. These "had the effect of breaking landforms into patterns, flattening out space and altering perspective" (Searle, 1991, p. 44).

Artistic investigation of spiritual issues of place resulted from the area's rich source of subject matter, and led many contemporary artists to focus on North Queensland from such an inspirational aspect. Wilson (1998) observes that well-known Australian artists such as Fred Williams (1927-1982), Brett Whiteley (1939-1992), Donald Friend (1915-1989) and Ian Fairweather (1891-1974) were “escaping society's settled civilized mode [to the complex natural systems of North Queensland as a] reaffirmation of life; a recognition of its inter-connectedness and its constant state of flux" (p. 172). Thus, although these artists painted in North Queensland, their paintings illuminated a general, non-geographical painting about life, rather than their art being a response to a particular location.

On the other hand, John Firth-Smith (b.1943), John Olsen (b.1928), John Coburn (1925-2006), and Anneke Silver (b.1937) are artists who have been inspired to develop art from deeply felt encounters with the North Queensland region. Documentation on these artists by Searle (1991), Ditchburn (1996), Drury (1998; Images 3), Wilson (1998), Mitchell (2000), Cree \& Drury (2000), and McDonald (2007) provides information about the conceptualisation and pictorial devices that have been used to portray these encounters in their art. For example, Cree \& Drury (2000) enlighten our understanding of Coburn's spiritual approach to painting through their description of him honouring a universe which they wrote was literally alive with the spirit, and regarded many of his abstract paintings as celebrations of the 
spiritual dance of life. They wrote that Coburn often utilised specific colours because of their emotional impact, and also used gold leaf to introduce a sense of the sacred. "For Coburn, spirituality is a universal aspect of our existence, regardless of the specifics of culture, and each of us can explore this through our creative potential" ( $p$. 96). This can be seen through his surprising eclecticism in the use of spiritual symbols such as a chalice and cross from Christianity, a Jewish menorah, a yin/yang symbol from Taoism, or a Hindu mandala. In his later work Coburn also acknowledged the Aboriginal bond with the sacred earth and nature by alluding to totemic forms in his painting and "believed it was time for us to relate to the land as the Aborigines do and have the same feeling for it" (Cree \& Drury, 2000, p. 96).

In terms of research, painting in North Queensland as artistic response to place has previously been conceptualised through both socio-cultural and spiritual theories as a mode of visual art communication. Samples of paintings from this region in the northeastern area of Australia have previously been studied for their different artistic elements to explore how this was done. For example, Searle (1991) examined a sample of works from 200 years of painting in North Queensland. While this particular sample expressed a response to the tropical environment and the landscape in North Queensland, none of the works were specifically analysed for their spirituality or sense of the divine. Hence, the focus of this research article was an exploration of the specific ways in which contemporary Australian painters embody a sense of the spiritual and a spiritual connection to the place that is North Queensland in their painting.

\section{Exploring spiritual responses to the place that is North Queensland}

In order to develop the stated research aim, the work of a group of four contemporary Australian painters was studied in relation to their visual language and spiritual connection to the place that is North Queensland. These established and currently practising artists were Anneke Silver (b.1937), John Firth-Smith (b.1943), Judy Watson (b.1959), and Barbara Cheshire (b.1946). Each of these artists' spiritual connection to place has previously been documented. Drury (1998, p. 135) comments as follows: "Silver's paintings reflect her long-standing interest in the relationship between spirituality and the landscape"; Firth-Smith's work "transcends formal rigour to embrace the sublime" (p. 143). Although Waanyi artist Judy Watson traces her matrilineal connection to country in her ethereal works, she also commented in a conversation with Hetti Perkins that she felt deeply about the country and was part of the North Queensland Conservation Council when in Townsville, North Queensland (Willsteed, 2007, p. 307). Nash comments that central to Cheshire's work "is the marriage of the physical and spiritual connections a person can have to a place" (Henson, 2010, p. 6).

In an attempt to explore and contextualise each of these artist's connections to place, including a sense of the spiritual, each artist's works was surveyed in order to identify a key painting which demonstrates a clear sense of the spiritual and a connection to North Queensland. Once an artwork by each artist was identified, they were analysed using a process of deconstruction. Deconstruction relates to many disciplines including, for example, literature. However, in relation to contemporary artwork, in this instance painting, Grosenick (2005) argues deconstruction is 
"a means of interpretation that regards a work not as a closed entity but as an open and many-layered network of the most varied elements in form and content. These elements, their functions and contradictions, are revealed by deconstruction." (p. 556)

Thus, the social conventions, compositional structures, and applied art materials in both physical and conceptual ways were considered. Each work was deconstructed by examining the internal production and the context from which it arose in order to open the painting's conditions of its production. This process of dismantling the artwork was used to reveal the comparisons and diverse meanings of spiritual connection to North Queensland. The findings of each artist and their work are discussed below.

\section{John Firth-Smith}

Although born in Melbourne, as a young man Firth-Smith's "escape to the north [gave him] a taste for freedom and independence [and allowed him] to develop his creative talents in the study and making of art" (Wilson, 1998, p. 115). As an abstract painter where the elemental context of water and air dominate his epic paintings in both subject matter and scale, hints of bounty from the ocean, surging tides, sunsets, and the cosmos have metaphorically infiltrated his work. He has become Australia's semiofficial painter of the sea (Crawford, 2011).

Elements such as this can be seen in the example Ritual (Figure 2) which also reflects Firth-Smith's large physicality in his art through brush mark and scale. The mood of the painting is fused through form and content inviting "the viewer to glimpse the sacred realm of the cosmos" (Drury, 1998, p. 143) through the density of colour field and the common symbol of the spiral. This symbol - which is found in nature, science, and art - is produced in the smallest virus and the largest galaxy. Science tells us the spiral movement which creates a centre and a whole is that which creates the solar systems, their suns, and planets. "These are the macrocosmic movements and cycles, mirrored in man the microcosm, which provide him with his model for all things cyclic, from sleep and emotions to time itself' (Purce, 1980, p. 8). In this work Firth-Smith transcends formal rigor and embraces the sublime through the use of the spiral, because it is also seen to signify the centre of power and life.

Despite North Queensland already providing a wealth of artistic and spiritual inspiration, Firth-Smith has visited the area again several times, and Wilson (1998) and Cree \& Drury (2000) observe that Firth-Smith still allows the paint to express what's happening above, below, and inside, as well through specific locations of the sea, sailing, and the shoreline and its boats. This spiritual understanding of his relationship with marine spaces and the cosmos still provides the source material and visual association for most of his paintings. 


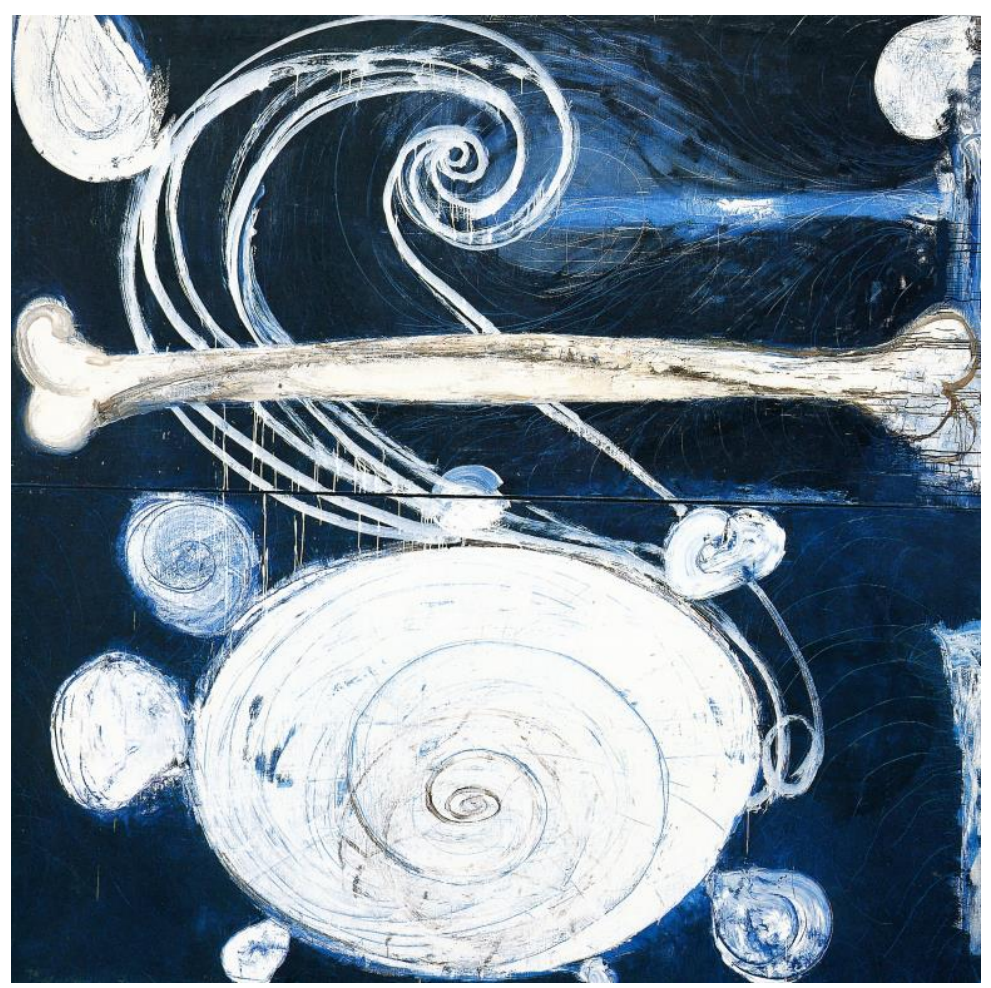

Figure 2: John Firth-Smith (1993-94), Ritual, oil on linen, $305 \mathrm{~cm} \times 305 \mathrm{~cm}$, courtesy of the artist and Robert Lindsay Gallery, Melbourne.

\section{Anneke Silver}

In contrast to the Australia-born Firth-Smith, Anneke Silver was born and educated in the Netherlands. After travelling in Europe, Egypt, and Indonesia, she arrived in Brisbane in 1959. Two years later, after exploring the wilderness areas of Queensland, she settled in Townsville (Drury, 1998). Her experience of the landscape here was spiritually overwhelming but she gained an intuitive understanding of the Aboriginal relationship with what they see as the sacred earth. She described this relationship between spirituality and her life in the landscape to Searle: "Ever since I came to North Queensland I have been acutely aware of the primeval quality of nature, as it is here so readily observed and felt. It is also strongly present at the various Aboriginal ... sites around Townsville and in Cape York' (Searle, 1989, p. 53).

Although being inspired by her European origin, mythology, and cultural anthropology, Silver commented in conversation with the authors, that she "cannot deny the influence of Aboriginal notion of sacred land on perceptions of landscape and spirituality. It certainly influenced me - the challenge is/was to translate this in Western cultural terms and not to copy Aboriginal art' (personal communication). Thus, the roots of both European and Aboriginal cultures contribute to her art, which she sees as a form of spiritual celebration that dances to a new rhythm surrounded by the Australian landscape.

In Time of Ritual (Figure 3), an early example demonstrating these cultural influences, traditional features of the Orthodox and Coptic icons echo through the wooden support and application of layering symbolic shapes. Through a methodology of abbreviation, the use of gold leaf and created symbolic shapes, Silver signifies the 
bush as a holy image, a sacred space in which the working of the cosmos can be observed and felt. She reflects that she is "intrigued by the fact that some of the pareddown tree and shrub shapes take on the look of some of the prehistoric figures" which deify the bush itself (Searle, 1989, p. 16).

Silver's artwork continues to signify an interconnectedness of culture, spirituality, and the landscape. Just being in and sensing the sites of North Queensland where there is no human interference, where there is dry land and waterholes, impact on and shape her personal and artistic life. Her love of these pristine landscapes evokes feelings of solidarity with indigenous culture, gratitude for beauty, and celebration of her stories from travelling in these dry areas.

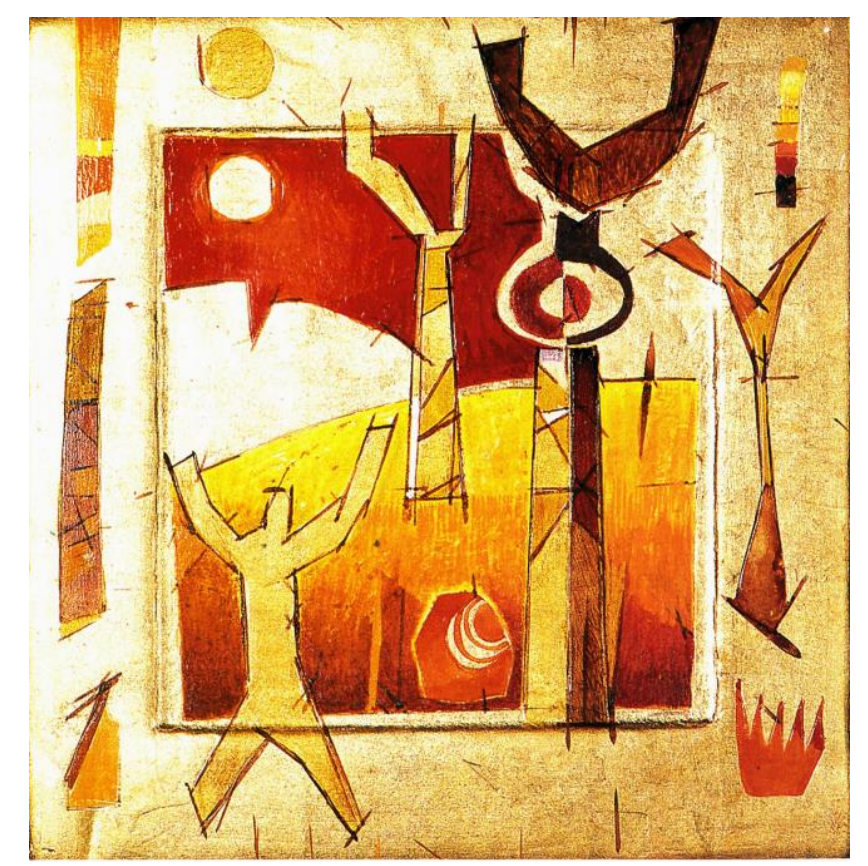

Figure 3: Anneke Silver (1989), Time of Ritual, mixed media and 24c gold leaf on timber, $25 \mathrm{~cm} \times 23.5 \mathrm{~cm}$, courtesy of the artist.

\section{Judy Watson}

Watson describes herself as a "cultural traveller", has completed projects in India, Italy, France, and the United States, and exhibited widely over the past 20 years (Gilchrist, 2011). Although she has lived in many parts of Australia, the spirit and substance of her artwork is grounded in her grandmother's homeland of the Waanyi people of north-west Queensland. However, it is notable that her ongoing experiences and understanding of the sacredness of the land, particularly in North Queensland, make environmental awareness instinctive.

Her drawings translate an imprint into the page of what has happened in the landscape, and her paintings reveal much about her spiritual and intellectual engagement with the world. She comments that she tries to "paint the land from both above and beneath to integrate the body with country" (Watson and Martin-Chew, 2009, p. 13). Her story embeds itself into her work with sensitivity to the 
methodologies that signify the internal and metaphysical landscape that straddles her two worlds. Both country and western (Watson and Martin-Chew, 2009, p. 14) are acknowledged. She comments: "I am Indigenous and non-Indigenous. I fit somewhere in between: I embody the notion of two cultural frameworks occupying the same cultural space" (Watson and Martin-Chew, 2009, p. 16). As Watson follows the path of her subject matter from the internal outward, she reinforces recognition of Aboriginal connections to country and their intrinsic spirituality. She clarifies that: "While much is revealed other things remain hidden from the eye if not the spirit" (Watson and Martin-Chew, 2009, p. 13).

In Larkins (2014), Watson revealed her view that if you were an Indigenous artist, you were of course political. Thus, the concept within Watson's work is often derived from a tough happening. It is signified by stripping objects of their visual rigidity and reinterpreting them in a subtle and subliminal way. The meaning is discovered in the layering of the media and imagery that floats throughout an abstract composition on stained canvas. Her distilled canvases have the power to speak to all. They become an organic map of experience. For example, Watson explains that A Complicated Fall (Figure 4) evolved as a result of the death in police custody of Mulrunji (Cameron) Doomadgee on Palm Island, North Queensland. Some of her relatives had also been sent to this island when it was a detention centre and part of her response to the combined happenings was an internal grieving. She became aware of this as she pushed and scrubbed raw pigments into the canvas. This beautifully spiritual, poetic and subtly political work is an intensely personal internal "grieving for and a scrubbing at the stain of the history of this country" (Watson and Martin-Chew, 2009, p. 110). Watson's work continues to tell her story, revealing cultural history while enriching viewers with the opportunity to connect and be part of her experience as they peel back the layers and "see the organism that is the country underneath, pulsating and beating like a heart" (Willsteed, 2007). 


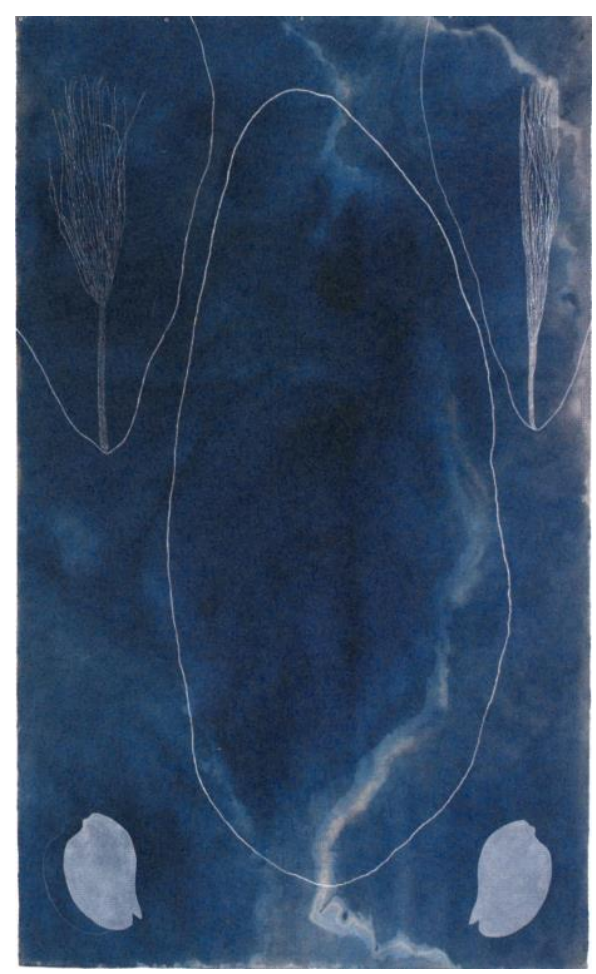

Figure 4: Judy Watson (2007), A Complicated Fall, pigment and acrylic on canvas, $217 \mathrm{~cm} \mathrm{x} 127 \mathrm{~cm}$, courtesy of the artist.

\section{Barbara Cheshire}

Cheshire was born and is based in North Queensland. She holds a $\mathrm{PhD}$ in Creative Arts and has 25 years of tertiary teaching experience. However, it wasn't until Cheshire was in her 40s that she began to feel truly passionate about art and see it as a means for personal spiritual exploration in paint. As a young woman her creativity was expressed mainly with fabric, needle and thread; more recently it has been purpose-driven (Wagstaff, 2007), that is, to depict the "complete human experience in landscape" (Henson, 2010). However, it took time for her to develop this approach. Cheshire states that she made a conscious decision to let go of all her formal training in favour of a meditative approach. The decision allowed her to look at the world by absorbing it rather than classifying it into categories by which we judge our environment. The painting Water Evening (Figure 5), centres upon the landscape as experience and the extent to which experiential and spiritual perceptions of all internal and external senses in response to an event or place can be transformed into visual art as a vehicle of communication.

The image signifies an encounter with spirit in place, drawing the artist and creation into itself. Water, signifying the refreshment of the spirit, starts as a little rain at the top and then forms into a centre of cool, strong power, which simultaneously bursts forth like a blossoming flower to rejuvenate and renew anyone contemplating the work. The process of rendering paint and form allows an instinctive, intuitive, experience to become meditative prayer throughout the physical application. Cheshire states that in spite of deep contrast and continual movement in the work, there was a deep, overwhelming experience of serenity while developing the rich, mysterious layers; an analogy to a serenity that comes from the deep layers within the soul, where 
the more one contemplates, the deeper the experience. Thus, this painting is more than just a visual representation, it is the complete picture of how this part of the world looked, smelt, felt, sounded, and tasted, as well as the artist's own strong spirit and her complete physical and spiritual response to place; a culmination of all that "is", the "I am" capturing the personal journey of spirit in this place that is part of North Queensland.

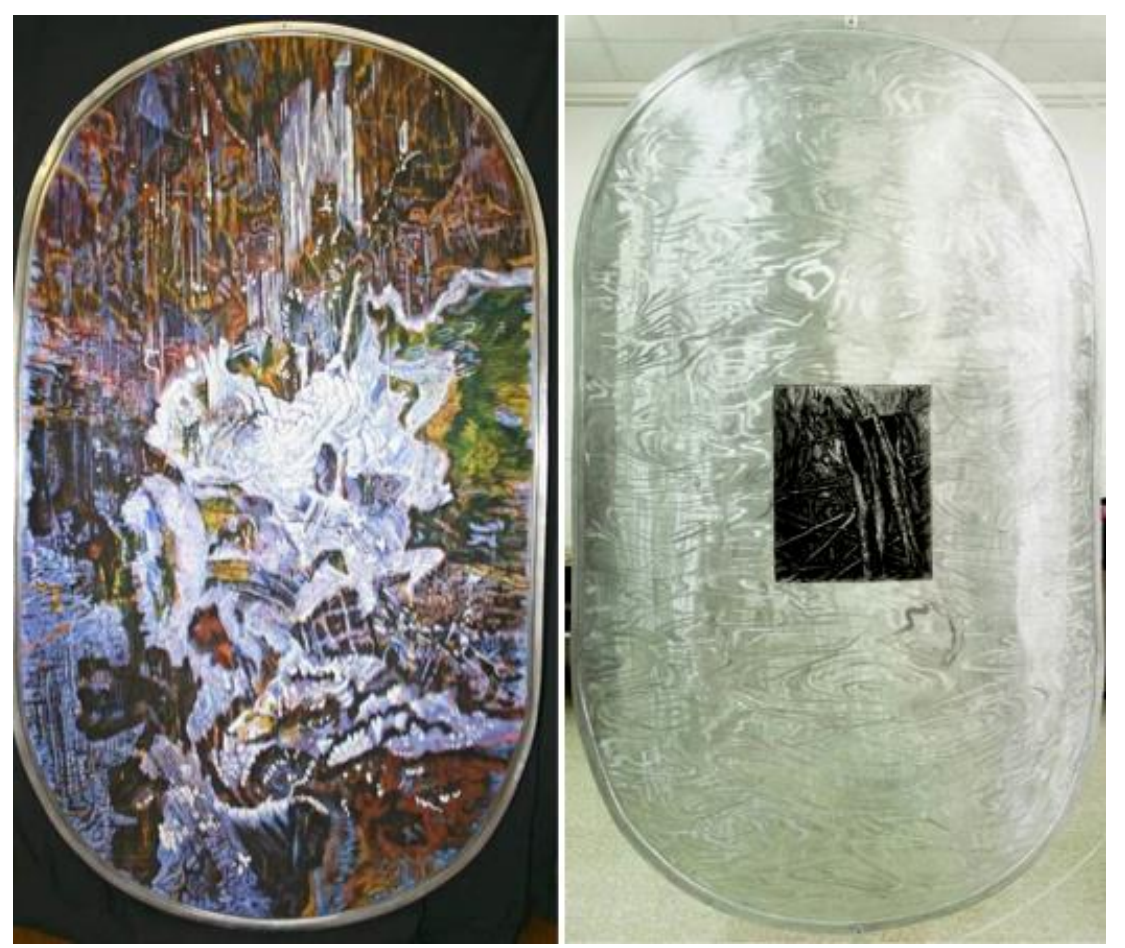

Figure 5: Barbara Cheshire (2008-2009), concave and convex of Water Evening Shield, aluminium primer with grit, gesso, and oil on aluminium, $200 \mathrm{~cm} \times 120 \mathrm{~cm}$, Courtesy of the artist.

\section{Discussion}

This article explores the work of four artists who have visually and artistically communicated their individual concepts of place that is North Queensland, including a spiritual connection. However, the decision at the heart of any artistic journey is a formulation of what is meant by art. Some term it as the form of human activity appealing to the imagination, but Barnhardt (1988, p. 119), argues that "the arts are civilisation's storehouse of felt values, the rendering of what has seemed important to those of powerful imagination and profound feeling and great mastery of expression". Through the deconstruction of these artists' different conceptual approaches, it can be seen how they have reinforced the fabric of their lives and their spiritual relationship with North Queensland. Each artist's conceptual signification demonstrates their social and cultural seal of individuality, which imprints a unique spiritual view of North Queensland in paint. Further, each idiosyncratic sense of identity gives deep impression to a viewer's understanding of the diverse ways that place can be represented through a spiritual relationship with it. 
Hence, while it is well documented in the literature (Drake, 2003) that artists have for a long time felt a strong aesthetic connection to place, this research reveals that a connection to place can also embrace a strong sense of the spiritual. Place often takes on an important role in our lives and "is the coming together of the biophysical, social, and spiritual worlds" (Vanclay, Higgins, \& Blackshaw, 2008, p. 3). Simply put, place is space that is special to someone. The personal meanings become embedded in people's memories to help define and save the experience. This is not new, and indeed all spiritual people have always had a sense of the importance of sacred places. What is new today is a growing awareness of how our experience of places and spaces shapes our spirituality (Hamma, 1999; Vanclay et al., 2008). Hamma (1999) argues the "who, the how, and the when of our spiritual lives derive their distinctiveness in large measure from the where ... The rhythm of the place where we live will likewise affect our spirituality" (p. 20-21).

\section{Conclusions}

For centuries the place that is North Queensland has offered painters both a link to the spirituality of the land and the opportunity to explore a connection between landscape and their own intimate sense of spirituality. This includes not only the traditional Aboriginal custodians of the land, but also painters from western origins who have either sought refuge in the tropics or based themselves in this location in order to present a creative and visual response. While this research has identified some of the key influences and underpinnings relevant to a small group of artists and selected works, there is ample opportunity to further examine connections to place in terms of painters in not only North Queensland, but further afield in other tropical regions of Australia, as well as around the globe. In addition, interviews with a group of artists who seek to encapsulate a sense of spiritual connection to the place that is North Queensland would offer new insights into this relationship and phenomena. While the works themselves will offer a lasting representation of these and other artists' connections to place, it is also the personal insights and reflections from the practitioners themselves that potentially represent an area of untapped knowledge and insight into the complexities and beauty of the human spiritual condition.

\section{Works Cited}

Au, W. (1989). By way of the heart: Toward a holistic Christian spirituality. New York, NY: Paulist Press.

Barnhardt, R. K. (Ed.). (1988). The Barnhardt dictionary of etymology. New York, NY: H W Wilson.

Cree, L. M. \& Drury, N. (2000). Australian painting now. Sydney: Craftsman House.

Crumlin, R. (1988). Images of religion in Australian art. Kensington: Bay Books.

Crawford, A. (2011). Collector's dossier: John Firth-Smith's voyage. Art Collector: The Only Magazine for Collectors, 57(July - September). Retrieved from: http://www.artcollector.net.au/CollectorsdossierJohnFirthSmithsvoyage 
Ditchburn, S. (1996). Plenty: Women artists of Townsville. Townsville: Perc Tucker Regional Gallery.

Drake, G. (2003). "This place gives me space': Place and creativity in the creative industries." Geoforum, 34(4), 511-524.

Drury, N. (1992). Images in contemporary Australian painting. Sydney: Craftsman House.

Drury, N. (1998). Images 3: Contemporary Australian painting. Sydney: Craftsman House.

Drury, N. \& Voigt, A. (1996). Fire and shadow: Spirituality in contemporary Australian art. Sydney: Craftsman House.

Gilchrist, S. (2011). Waterline brochure. Brisbane: The Queensland Government, Australia through Queensland Indigenous Arts Marketing Export Agency. Retrieved from: http://archive.tolarnogalleries.com/archive/Judy\%20Watson\%20waterline\%20 2011/files/data/search.xml

Grosenick, U. (2005). Art now: The new directory to 136 international contemporary artists. Cologne: Taschen.

Gunton, C. E., (Ed.). (1997). The Cambridge companion to Christian doctrine. Cambridge: University Press.

Hamma, R. M. (1999). Landscapes of the soul: A spirituality of place. Notre Dame, IN: Ave Maria Press.

Henson, J. (Ed.). (2010). Art gaze: Townsville's art magazine.

Keating, T. (1996). Intimacy with God. New York, NY: Crossroad Publishing.

Larkins, D. (2014, July 11). Judy Watson: Trailblazing in modern Indigenous art. Retrieved from: http://www.abc.net.au/local/photos/2014/07/09/4042417.htm

Leder, D. (2004). Sparks of the divine: Finding inspiration in our everyday world. Notre Dame, IN: Sorin Books.

McDonald, J. (2007). Australian painters on the nature of creativity. Singapore: Tien Wah Press.

McFague, S. (1993). The body of God: An ecological theology. Minneapolis, MN: Fortress Press.

Mitchell, A. (2000). John Coburn: Spirit of abstraction, Art Collector: The Only Magazine for Collectors, 14(October - December). Retrieved from: http://www.artcollector.net.au/JohnCoburnSpiritofAbstraction

Moon, B. L. (2004). Art and soul: Reflections on an artistic psychology. Springfield, IL: Charles C Thomas.

Nganjmirra, N. (1997). Kunwinjku spirit: Creation stories from Western Arnhem Land. Melbourne: Melbourne University Press.

Nicholls, C. \& North, I. (2001). Kathleen Petyarre: Genius of place. Adelaide: Wakefield Press. 
Purce, J. (1980). The mystic spiral: Journey of the soul (art and imagination). London: Thames and Hudson.

Searle, R. (1989). Ancestral meetings: An exhibition of recent work by Anneke Silver. Townsville: Perc Tucker Regional Gallery.

Searle, R. (1991). Artist in the tropics: 200 Years of art in North Queensland. Paddington: Rainforest Publishing.

Siedell, D. A. (2008). God in the gallery: A Christian embrace of modern art. Grand Rapids, MI: Baker Publishing Group.

Vanclay, F., Higgins, M., \& Blackshaw, A. (Eds.). (2008). Making sense of place: Exploring concepts and expressions of place through different senses and lenses. Canberra: National Museum of Australia Press.

Wagstaff, C. (Ed.). (2007). Art Edit Mag.

Watson, J., \& Martin-Chew, L. (2009). Judy Watson blood language. Melbourne: The Miegunyah Press.

Were, I. (Ed.). (2003). Story place: Indigenous art of Cape York and the rainforest. Brisbane: Queensland Art Gallery.

Willsteed, T. (Ed.). (2007). One sun one moon: Aboriginal art in Australia. Sydney: Art Gallery of New South Wales.

Wilson, G. (1998). Escape artists: Modernists in the tropics. Cairns: Cairns Regional Gallery. 